\title{
A Review Study on Socio-economic Causes of Juvenile Delinquency
}

\author{
Sartaj Ahmad ${ }^{1}$, Bhawana Pant ${ }^{2}$, Monika Gupta ${ }^{2}$, Alka Singh ${ }^{3}$, Reena Bishnoi ${ }^{4}$, \\ Manoj Kumar Tripathi ${ }^{5}$ \\ ${ }^{1}$ Associate Professor (Medical Sociology), ${ }^{2}$ Professor, ${ }^{3}$ Junior Resident III, Department of Community \\ Medicine, Subharti Medical College, Meerut UP India, ${ }^{4}$ Associate Professor (Law), Subharti Law College, \\ Swami Vivekananda Subharti University, Meerut UP India, ${ }^{5}$ Associate Professor (Political Science and Public \\ Administration), Subharti Law College, Meerut UP India
}

\begin{abstract}
Juvenile delinquent is a person under age, who is guilty of anti- social act and whose misconduct is an infraction of law. The problem of "Juvenile Delinquency" is a very vague issue that consists of a lot of contingencies and is also open to a number of apprehensions and interpretations as to how, when and what preventive methods should be used to prevent such delinquent behaviour among the adolescents of our nation.
\end{abstract}

Keywords: - Juvenile Delinquency, Psycho- socio-economic factors, physical factors, Legal remedies and prevention

\section{Introduction}

According to the Juvenile Justice Act 2015, “ the child between the age group of 16-18 years who indulges in anti social activity". The main factors related to juvenile delinquency arei) Social factors ii) Economic Factors iii) Physical and mental .

Social Causes of Juvenile Delinquency

Some of the social causes which may contribute to Juvenile delinquency are:

\section{i. Family environment}

A reliable example of family risk elements

\section{Corresponding Author:}

\section{Dr Alka Singh JRIII}

Department of Community Medicine, Subharti

Medical College, Meerut, U.P., India.

Email- alkasingh24593@gmail.com

Contact 8126134643 relate to the improvement of reprobate conduct in youngsters. These family hazard factors incorporate an absence of appropriate parental supervision, less surveillance on the child, progressing parental clash, disregard, and misuse like emotional, psychological or physical. Guardians who exhibit an absence of regard for the law and social standards will probably have youngsters who think.

Broken Homes:-In broken families, where family ties and mutual intimate relationships have been destroyed. Broken homes may be considered as a very important factor in Juvenile delinquency.

Parent- child relationship:- When the child is deprived of love and is scolded constantly on every occasion, child develops feeling of revolt and hatred, so much that he could run away from the home and falls into a life of crime. Parental care and affection may be lacking through the following causes: a. Mother working. b. Mother occupied in social activities. c. 
Lack of undivided attention due to many children in family . d. Lack of interest and understanding.

\section{Ill-treatment by Foster Parents, Step-parents} or Guardians:-

Achild may resent the fact that he has to have foster parents, stepparents, or guardians and so be marked out from the other children, which will make it difficult for these people to help in his social development. Because of this resentment their influence on child bywork or example, becomes less potent. The child cannot be guided painlessly and unwittingly along the path to good conduct through the aid of his natural suggestibility.

Lack of parental care love and affection:-The feeling side of a child's personality needs proper nourishment for healthy development just as his body does. The child who is deprived of sympathy and affectionate attention at home misses his first example and training in good fellowship, kindness and consideration for others. He misses the momentary relief and rest from personal responsibility so refreshing and necessary if he is to take on his share of social responsibility, as a child among his playmates and later on as an adult.

\section{Home Conditions}

Home conditions can only be indirect causes of delinquency. They react upon the child's mind and body altering his mental and physical condition which in their turn determine his behavior. The conditions in the home and the family relationships which influence more particularly the mental life of the child are perhaps even more important as causes of delinquency than factors which affect mostly the physical condition of the child. Coming from the same home environment one child may become delinquent while his brother may become a great thinker or reformer.

\section{Congested Neighborhood and Slums}

Congested neighborhoods and slums may cause delinquency for the same reason that overcrowded homes and schoolrooms may do. Slums may include additional causative factors such as bad sanitation, damp, dark and badly ventilated houses, proximity of smoky, smelling factories and noisy machinery, and the close contact with undesirable neighbors, perhaps immoral and delinquent. Children are not so likely to get into bad mischief while they are alone, but when they get together in gangs as they do in congested neighborhoods, they become fortified by mutual support and are ready to dare anything. The influence of a gang is further considered under separate heading.

\section{Lack of Recreational Facilities}

Just as lack of recreational facilities in school leave a child practically no socially desirable outlet for, and means of discipline for normal or abnormal impulses during school hours, so lack of similar facilities in the neighborhood presents the same and even greater difficulty for out-of-school hours. Investigators have shown us that crimes are mostly committed in spare time, that is, time spent away from school or work. It is therefore considerably more serious for a child to live in a neighborhood without play-ground space, clubs, or game facilities of any kind, than it is for him to attend a school deficient in the same respects. Although, as has previously been shown, this latter deficiency may have serious enough consequences itself. Any and all kinds of delinquency may result from lack of recreational facilities.

\section{Use of Drugs and alcohol}

This is not an important factor in juvenile delinquency, though it may play a part in the causation of crime in later adolescence and more particularly in adulthood. It is a delinquency in itself, but, like truancy, it may also be a causal factor in other delinquency, such as stealing, sex offenses, or disturbing the peace.' A great variety of mental, 
physical, and environmental factors contribute to drug addiction as to any other form of undesirable behavior.

\section{Sex Habits and Experiences}

Sex habits such as masturbation or illicit sex experiences may lead to further sex delinquencies or may have other consequences. The tendency to sexual and other forms of delinquency is thus increased.

\section{Habit and association}

One of the most difficult of the psychological causes of delinquency to treat and one of the most potent is that of habit. A delinquency once committed, as the result of suggestion, fleeting impulse, temporary loss of control or from whatever cause, may be repeated more or less automatically by force of habit. A habit develops when mainly pleasant and few unpleasant consequences follow the action. The more often the delinquent behavior is repeated and the more it is attended with pleasant circumstances, the more established becomes the habit. This delinquent habit may persist long after the original cause of its existence has disappeared. A psychiatrist, for instance, may discover and actually remove the causes which led a boy to steal, pick pockets, lie or stay out at nights, but still the young man may keep up his delinquent ways because of habit. Psychologically speaking, habits exist because bonds of association have been formed between the situation and the response.

\section{Influence of Gangs and Gang Codes}

The increased suggestibility of an individual in a group of people is one of the most striking features of "mob psychology." Further, if the group be banded together for any set purpose the individual members become more suggestible to thoughts or actions bearing any connection with the aim of the group. For instance, if a gang be formed for the purpose of playing practical jokes any mischievous suggestion from one of the number will be quickly taken up by the others and eventually serious delinquencies may be committed.

\section{Over stimulating Movies and Shows}

Among juvenile offenders many have been found to be ardent frequenters of movies and vaudeville shows. According to Judge of Cincinnati considers these latter to be very powerful factors in the determination of juvenile crime. It is thought that shows and movies stimulate the children's primitive instincts for adventure, conquest, acquisition, etc.; and that many of them offer suggestions for active expression of these instincts along delinquent lines, which may be carried out later by the children. Some children's minds may be too immature to distinguish between the lawful and the unlawful, the moral and the immoral of what they see enacted before them; thus, should they copy what they see, they may be led to commit social offenses unwittingly. Others, who are old enough to distinguish between right and wrong, may be urged to delinquency by the excitement aroused within them and the daring suggestions offered by the show. On the other hand, movies and shows offer many suggestions for socially desirable behavior which are presented in such a manner that they are more likely to take effect than the bad suggestions. It is possible also that witnessing an exciting show may be a good substitute for primitive instinctive and emotional activity and in some cases may be a curative measure rather than a cause of delinquency.

\section{ii. Schooling environment}

School conditions, may be considered as indirect causes of Juvenile delinquency. It is the effect which these conditions have upon the particular child's mind and body which actually causes delinquent behavior. Conditions in school which contribute to delinquency are as follows: 


\section{Inadequate School Building and Equipment}

These may be primary causes of unhealthy bodies and general incorrigibility in school children. Overcrowded, badly ventilated classrooms, perhaps also poorly heated and lighted, make discipline as well as good health among the pupils well-nigh impossible. Insufficient staff and non-provision of necessary books and apparatus often means that the children's time is only partly occupied and even then probably in a very dull way from the child's point of view. The forced or the stolen idleness gives them plenty of opportunity to plan and to carry out deeds of mischief.

\section{Inadequate facilities for recreation}

Lack of playground, gymnasium and other facilities for games represents lack of the only means, at the present time, for the social outlet and training of the instincts. Such deficiencies also deprive the children of a valuable general as well as mental hygiene measure.

\section{Poor Attendance}

Attendance laws which include many exemptions from attendance give ample opportunity to the rebellious child, the dissatisfied child, or the adventurous child to play truant and avoid immediate consequences. He can always find some plausible excuse for being away from school.

\section{Poor discipline}

A teacher who does not keep all the pupils happily engaged, a teacher who allows freedom one minute and who is strict with the children concerning the same things another minute, a teacher who expects mischief and challenges the children (consciously or unconsciously) to defiance of order and authority, or one who is generally incompetent at his task, will be sure to find at least some of his pupils delinquent.

\section{Strict behaviour of teachers}

Sarcastic teachers may produce rebelliousness, aggression or timidity in children. Noisy teachers may provoke noisiness, antagonism and even violence. Badtempered teachers may arouse anger and pugnacity in children, or fear and nervousness. Nervous or psychopathic teachers may induce symptoms similar to their own in the pupils. General incorrigibility, truancy, lying and fighting may be the direct outcome of any of these conditions, while stealing and other offenses may be indirectly traceable to these causes.

Bad School Companionship or influence of bad Companion

Children may get together for laudable purposes or to support one another in mischief. But whatever be the cause or purpose for a group's getting together, the individual members will influence one another's behavior through suggestibility which becomes exaggerated in group life. The children most open to such influence are those whose own training has been neglected or faulty, children who have not learnt to appreciate the difference between good and bad behavior, or those who care little for the approval and disapproval of parents and teachers.

ECONOMIC CAUSES OF JUVENILE DELINQUENCY

Some of the economic causes which may contribute to delinquency are:

Poverty :-Poverty is one of the significant purposes behind juvenile delinquency, a huge extent of reprobate youngsters originates from poor homes. It is notwithstanding how not recognized by proficient understudies of adolescent misconduct; the vast majority of delinquents originate from the lower class. They submit their offences as an individual from packs. Poverty compels sometimes both of the guardians to be outside the home for a very extensive 
stretch to gain their everyday bread, to full fill basic needs, hunger.

Unemployment:-Unemployment causes a similar condition of affairs. Statistics in the large cities show that during severe winters and depressions in trade, robberies, "hold-ups," and-thefts increase in number. Youthful or grown-up, may prompt an off-base way to improve their budgetary conditions. Adolescents become adolescent delinquents because of the absence of accounts.

Irregular Occupation:- Irregular and seasonal occupations and those which do not offer steady wages place the young worker in the difficult situation of having too much alternating with too little money. The child who makes considerable sums of money and has ample pocket-money at one season and who is entirely without at another may be tempted to steal during the "off" periods. He may resort to stealing to keep up appearances and reputation among his companions, or to satisfy taste or greed for luxuries developed during the periods of affluence.

Occupational misfit:-Young boys and girls engaged in occupations ill-suited to the unnatural aptitudes or physical condition may develop attitudes of discontent, restlessness, irritability, nervousness or despondency. They may also get over-fatigued and fall sick. These conditions may lead them into delinquency for compensation or because their power of control and resistance is so reduced that they cannot help it.

\section{Proximity of Luxury and Wealth}

Children whose parents are comparatively poor and who live near to a more wealthy district may develop attitudes of discontent or longings for the luxuries of the others, so much so that they commit crimes to get even with the others or to satisfy their material cravings. If their companions are children of more affluent parents the poorer children may steal in order to be of equal standing with their little friends.

Spare time and Idleness:-A youth may have spare time because his work only fills a small part of the day. He may be constantly drifting from one job to another unable to find a suitable occupation, each change meaning time out of work, or he may be engaged in a seasonal occupation which of fords weeks of spare time. During these idle hours he may indulge in some form of delinquency for his own amusement satisfaction, or he may join a gang and be drawn into criminal pursuits.

Truancy:-Truancy from work or school provides ample opportunity and spare time for delinquency. It usually happens during the part of the day when desirable companions are not available for play or other purposes. The truant then must either spend his time in solitude or in the company of other young or older delinquents.

Malnutrition:-Malnutrition may cause inertia and mental sluggishness or hyper excitability and nervousness in a child. Any of these conditions may lead to delinquency. The child may become the sport of bad suggestion or the tool of his own feelings and impulses. Or he may compensate for his disabilities in delinquent conduct.

Preventive measures and remedies to control of Juvenile Delinquency

Any juvenile crime, how small or big it is, the child is not the one to blame; it is surrounding there could be many reasons but not the child. When it is not the child, making a strict law will not bring change and will not stop juvenile delinquency.

\section{i. Probation}

Juvenile Delinquents are kept under the supervision of a probation officer, whose job is to look 
after the delinquent, to help him in getting established in normal life and to see that the delinquent observes the rules of bail- bond. Thus the delinquent not only gets a chance to reform himself, but also gets advice and concrete help.

\section{ii. Reformatory Institutions}

To reform inmate delinquents, the institutions provide an all round personality development by sufficient means of separating the intimates by providing adequate facilities to meet the basic needs such as proper Isanitary arrangement, water supply, food clothing and bedding for the inmates and vocational or industrial training. When delinquent becomes sick medical aid will be provided.

\section{iii. Certified Schools ( Fit Persons Institution)}

These are established for the treatment of Juvenile Delinquents. The schools are of two types:

1. Junior school below 12-13 years of age.

2 . Intermediate school 13-15 years of age.

3 Senior school between 15- 17 years of age.

The children are generally confined there upto a certain age limit and for about 2-3 years, but the school authorities can make an early discharge. After their release they are kept under the charge of a welfare officer or probation officer.

iv. Auxiliary home

They are attached to certified schools here the delinquent are kept forsome time and studied by a social worker and then they are sent to the certified school according to the nature and aptitude of a young offender.

\section{v. Foster homes}

They are specially for delinquent children of under 10 years of age who cannot be sent to approved or satisfied school unless the court is satisfied that they cannot be dealt with otherwise. They are generally run by voluntary agencies added by the government.

\section{vi. Uncared children institution}

The children in the pre delinquent or near delinquent stage, who are mostly founded in a state of destruction or neglect are care for. All over the country they are situated,managed by private philanthropist.

\section{vii. Reformatory school}

These are meant for the education and vocational training of delinquent children with much regarding to the type of crime committed.The delinquent are removed from base Government and place in the reforming school for some time after which they cannot adopt some vocation learnt in the school young offenders, under 15 years are imprisonment for 3 or 7 years.

\section{viii. Borstal Institution}

It is a system of detaining juvenile delinquent first correctional propose of reformatory is at borstal special treatment is provided for adolescent offenders between the age of 15-21 years. There are two types of borstal institutions.1. Open institutions- open environment with no surrounding well.2. Closed institutions- converted person building where maximum security provided.

\section{ix. Psychological techniques}

a. Play therapy: The delinquent children are given opportunities to participate in such place which give expression to the repressed motives and help in the development of the creativity and energy.

b. Finger painting: The child is given plain paper and some colors child are allowed to paint in this own way. The purple is not painting but expression of repressed motive in the child which leaves them sensible and healthy. 
c. Psychodrama: The child is allowed to participate in different role in group drama and there by manifest their repressed motives the psychologist reform delinquent by creating healthy atmosphere in the family and by providing and adequate recreation coordination and efforts of teaching, guardian and government are required to organize psychodrama by delinquent children.

\section{Conclusions}

Juvenile delinquent involves wrong doing by a child or a adolescent person, who is under age specified by the law of the place concerned. Juvenile delinquent, who breaks the law, is a vagrant, persists in disobeying orders, whose behaviour endangers his own moral life as well as the moral life as well as others around them. Juvenile delinquency is a social problem. Adolescent misconduct is one that has drawn the consideration of Indian society too. It realized that the reprobate kid today may end up being an interminable criminal tomorrow. So Juvenile delinquency should be controlled by socially and financially.
Ethical Clearance : Not Required

Source of Support: Nil

Conflict of Interest: Nil

Acknowledgement: None

\section{References}

1. IPC Section 82 - Act of a child under seven years of age [Internet]. A Lawyers Reference. [cited 2021Nov17]. Available from: https://devgan.in/ $\mathrm{ipc} / \mathrm{section} / 82 /$

2. Hirschi T. Causes and Prevention of Juvenile Delinquency. The Craft of Criminology. 2017;:105-20.

3. Juvenile Delinquency in India Causes and Prevention [Internet]. Legal Service India - Law, Lawyers andLegalResources. [cited2021Nov12]. Available from: http://www.legalserviceindia. com/legal/article-1724-juvenile-delinquency-inindia-causes-and-prevention-.html 